\title{
The correlation of industrial work experience and soft skills on work readiness of graduated of vocational high school
}

\author{
Diana Nur Azizah*, Supari Muslim \& Mochamad Cholik \\ Department of Tecnology and Vocational Education, Pasgraduate Program, Surabaya State University, East Java, 60231, Indonesia \\ diana.18007@mhs.unesa.ac.id; supari@unesa.ac.id; mochamadcholik@unesa.ac.id \\ *Corresponding Author : diana.18007@mhs.unesa.ac.id | Phone Number: +6281333427010
}

\section{ARTICLE INFO}

Received: 15-05-2021

Received in revised: 18-06-2021

Accepted: 15-07-2021

Available online: 30-8-2021

\section{KEYWORDS}

Soft skills;

Industrial practical work;

Experience;

Work readiness;

Vocational school students;

\begin{abstract}
A B S T R A C T
The demands of the world of work require that every student must have competence. Work readiness to enter the world of work can be influenced by several factors. Do soft skills and industrial practical work experience affect vocational students' work readiness? This study aims to obtain a correlation between practical industrial work experience and soft skills on vocational school students' work readiness with quantitative methods through a questionnaire using google form at Vocational High School of RadenPatah, Mojokerto, class XII, majoring in Mechanical Engineering. The data obtained from 72 students in the sample were analyzed by using the Multiple Regression Test using SPSS 23 software. The results of this study indicate: (1) there is a significant correlation with the direction of a positive relationship between industrial work practice experience and work readiness of $24.4 \%$ (2) there is a significant correlation with the direction of the positive relationship between soft skills and work readiness of $25.4 \%$ (3) there is a significant correlation with the direction of the positive relationship between industrial work practice experience and soft skills simultaneously to work readiness by $31.1 \%$.
\end{abstract}

\section{INTRODUCTION}

Government Regulation Number 29 of 1990 concerning Secondary Education states that Vocational High School is an education with a secondary education level which prioritizes the development of students' abilities to carry out a type of work based on their expertise. Vocational High School education prioritizes the preparation of students to enter the world of work as well as developing a professional attitude. Based on the form, Vocational High School organizes an educational program which is implemented according to the type of work field.

Data from the Central Statistics Agency shows that the Open Unemployment Rate (OUR) as of February 2020 is 137.91 million people. The largest percentage based on education was held by Vocational High School graduates, namely $8.49 \%$. This shows that vocational school graduate students are vocational education that should prepare students to work when graduating has not been fully implemented. Government efforts in improving the quality of learning and improving the quality of education and retraining programs are stated in the latest Minister of -
Education and Culture Regulation number 22 of 2020. In the previous period 2015-2019, one of the priorities for education development was increasing the relevance of graduates. In the 2020-2024 period in accordance with Presidential Instruction No.9 of 2016 concerning Vocational High School Revitalization, in order to improve the quality of human resources, the Ministry of Education and Culture has made several efforts so that Vocational High School graduates are of high quality and relevant to the needs of Industry, Business and the World of Work (IDUKA).

There are five purposes for the revitalization of Vocational High School, including (1) realizing link and match between schools and IDUKA; (2) changing the new paradigm from push to pull, this paradigm changes that Vocational High School, which was previously only encouraging to produce graduates without paying attention to the needs of the labor market, has turned into a new paradigm, namely looking for everything related to the job market for a harmonized form of Vocational High School 
curriculum. along with the industry curriculum; (3) changing the learning model from supply driven to demand driven; (4) prepare Vocational High School graduates who are adaptable to changes in the business world to become graduates who can work, continue to higher education, and become entrepreneurs; (5) eliminating or reducing the gap between vocational education and IDUKA's needs in terms of administration, technology, and competence (http://disdik.jabarprov.go.id, 2018). Vocational revitalization encourages students to have work readiness who have the ability to adapt to developments and changes in the world of work.

Efforts to improve the quality of Vocational High School graduates include the curriculum, educators and education personnel, cooperation between IDUKA and graduates. Of course, this must also be supported by facilities or the availability of infrastructure at schools. The availability of infrastructure such as laboratories/workshops at Vocational High School is absolutely necessary. In addition, the ever-changing development of the world of work makes Vocational High Schools have to prepare graduates with the skills needed to get jobs (Weili and Chenwei, 2018). Skills and training so that they are ready when they enter the world of work, students can also get them outside school through industrial work practices.

Vocational High School graduates are expected to master not only hard skills but also have soft skills. Malhi (2010) recommends that vocational high schools should adopt a holistic and integrated approach to improve graduate employability, the soft skills component that needs to be improved consists of self-reliance, student involvement in work-related projects and extra-curricular activities, job placement, and guidance on skills. career services focused on minimizing skills gaps. In order to achieve this goal, Vocational High Schools must implement a learning system that is transform of knowledge and transform of value in a balanced manner. However, in general education in Indonesia, especially Vocational High Schools, currently emphasizes hard skills and provides less soft skills. This skill gap is a challenge for Vocational High Schools not only in Indonesia but globally. This is one of the factors that causes the low quality of Vocational High School graduates.

The results of observations made at Vocational High School of RadenPatah, Mojokerto regarding tracing data for XII grade students of the 2018/2019 academic year showed that $63 \%$ of graduates were absorbed in the world of work. This figure is still not enough to meet the success of graduates with the absorption of graduates in the world of work as much as $75 \%$. However, this can be influenced by internal or external factors from the students themselves to have work readiness.

Based on the explanation above, factors that have a correlation and can affect work readiness are industrial work experience and soft skills. The two factors will be used by researchers as research variables at Vocational High School of RadenPatah, Mojokerto. The objectives of this study were to determine: (1) the correlation of industrial work practice experience with work readiness; (2) the correlation between soft skills and work readiness; (3) correlation of industrial work practice experience and soft skills on work readiness.

Soft skills are a person's skills related to themselves in managing themselves or called intrapersonal skills and skills related to other people or called interpersonal skills to be able to work optimally. According to Berthal (Muqowim, 2012) soft skills are individual or personal behavior and between individuals or interpersonal which develop human performance to the maximum. According to Putra (2005) that soft skills are the invisible abilities needed to achieve success, such as the ability to communicate, about honesty or integrity and others. According to Sailah (2008) soft skills are defined as the behavior of interpersonal relationships and with their own personalities which are developed and human performance is made optimal, such as teamwork, training forums, communication decision making, initiative, adaptability, conflict resolution, leadership, problem solving, etc.

Soft skills have an important role in determining someone's success in their work (Wagiran, 2008). There are two factors that influence the formation and development of soft skills, namely internal factors and external factors. Internal factors are factors that come from within students, including interest, motivation and opening up to improve and develop themselves for the better (Rokhimawan, 2012: 51). Meanwhile, according to Syarifuddin (2011: 131) external factors are factors that come from outside the student and the environment. These external factors are the habituations that take place in every activity ranging from social interaction to other activities.

Broadly speaking, soft skills can be classified into two categories, namely intrapersonal skills (the ability to control oneself and interpersonal skills (the ability to relate to other people) (Iskandar, et al., 2014). Interpersonal skills are skills that relate to or interact with the community and environment groups. work and interaction between personnel or individuals Some examples of interpersonal skills include leadership skills, communication skills, public speaking skills, teamwork and negotiation skills, while intrapersonal skills are self-regulating skills. This is the main thing before someone builds relationships with other people, including self-confidence, character transformation, proactivity and time management.

According to (Goleman, 2002) soft skills used in the world of work consist of personal skills and also social skills. Personal skills (intrapersonal skills) are abilities that determine how to manage and organize yourself. This 
ability includes self-management and self-awareness. Meanwhile, social skills (interpersonal skills) is the ability of how to personally manage and manage relationships. This ability includes social awareness and relationship management. The purpose of soft skills training is to provide opportunities for students to learn new behaviors and improve personal relationships with others. Soft skills training improves student potential, makes the workforce more flexible, has a positive attitude to change easily, is able to handle various changes in work demands and is more competitive (Rani, 2010).

According to Chalpin (2006) experience is knowledge or skills obtained from practice or from outside the learning effort. Experience can also influence the physiology of individual development, which is one of the principles of development of vocational school students' readiness in preparing to enter the world of work (Dalyono, 2005). According to Hamalik (2007), experience is broadly divided into two, namely: (1) substitute experiences obtained through pictures, through direct observation, through words, through graphics, and through symbols. (2) direct experience gained because of direct participation and action, experience can be gained through education and training.

The characteristic that distinguishes Vocational High School graduates from other graduates is genuine work experience. Industrial Work Practice is part of a dual system of education which is an innovation of Vocational High School education where students intern in an industry that is relevant or according to their competence (expertise) which time is certain (Firdaus, 2012: 400). Industrial work practice is an opportunity for students to gain and improve skills and knowledge. Industrial work practice in several schools is termed On The Job Training (OJT), which is a training model with the aim of providing the skills needed in work in accordance with its vocational relevance and job demands (Hamalik, 2007: 21). According to Dikmenjur (2013: 20) industrial work practice is a compulsory program that must be taken and organized by schools, especially vocational and non-school education which must be followed by students. Through industrial work practice students can add to their experience, have carried out the factualization process in the world of work because they can test and compare what is obtained in school in the form of theoretical knowledge with real situations or real situations.

The objectives of holding industrial work practices (Dikmenjur, 2013) are: (1) Producing a workforce of good quality, namely workers who have the skills, knowledge and job highs that are in accordance with the demands of the job field. (2) Obtain a link and match between Vocational High School and IDUKA. (3) Improve the efficiency and effectiveness of the education process and job training with good quality. (4) Give recognition and appreciation to work experience and is part of the educational process. IDUKA has a role in helping the implementation of apprenticeship in achieving student competencies and has a positive effect on the recruitment of new workers. IDUKA can select new employees from vocational school students who do internship according to the required competencies.

The implementation of industrial work practices can help students to strengthen the learning outcomes obtained at school as well as equip students with real experiences in accordance with the learning program they choose. According to Hamalik (2007) industrial work practice provides the following benefits: (1) Providing opportunities and opportunities for students to practice management skills in actual field conditions. (2) Provide practical experience to students and can add or enrich the quality of practice. (3) Students have the opportunity and have the opportunity to solve various problems in the field by utilizing their abilities. (4) Bringing students closer to assignments and bridging the preparation of students to enter the world of work according to their field of work after taking industrial work practices. Based on the description, industrial work practices provide benefits for students to gain experience in the world of work and business and foster students' self-confidence. While participating in industrial work practices, students can train to support skills that have been learned in school to be applied to the workplace (industrial work practice), be able to know and live the work environment, which in the end students are ready to work in the business world and the industrial world after graduated from Vocational High School.

Work readiness is a process to reach a goal by involving the development of student work which includes knowledge, skills, attitudes and values. (Firdaus, 2012). According to Sugihartono (2000) work readiness is a situation that shows harmony between mental maturity, physical maturity, and learning experience so that personnel have the ability to carry out certain activities or activities in relation to work.

The characteristics of students who have work readiness according to Fitriyanto (2006) are students who have the following considerations: (1) Having objective and logical considerations. Students who are old enough have more consideration, do not see only one side, but will connect with other things, and by seeing the experiences that other people have had. (2) Have the willingness and ability to cooperate with other people. A work that will be completed together requires a relationship with many people, and to establish cooperation in the world of work. For that, students are required to be able to interact with many people. (3) Having a critical attitude. Being critical in attitude is needed to be able to correct a previous mistake, and then will be able to decide what kind of action can be 
taken after the correction is made. Being critical is needed when working because it can foster initiative and creative ideas to improve quality work. (4) Having the courage to accept responsibility independently. Working independently requires a responsible attitude towards every worker. Responsibility will arise from students when students have surpassed mental and physical maturity accompanied by awareness that arises from the individual. (5) Has the ability to adapt to the environment. Adjusting to the environment, especially the work environment, is an asset to be able to interact together with the environment. This can be started from the time before entering the world of work which is obtained from the experience of industrial work practices. (6) Have the ambition to be able to advance and try to follow the development path of the existing expertise competencies. The desire to move forward becomes the basis for the emergence of student work readiness so that they are motivated to get something better. One of the efforts that can be done is to follow the development of competencies or areas of expertise.

Based on the description above, that vocational graduate students are said to have work readiness if they have a level of maturity, both physically and psychologically, have experience in learning, have objective and logical considerations, willingness and ability to work with others, are critical in attitude, dare to accept responsibilities in personnel, have the ability to adapt to the environment, and have the ambition to move forward and try to follow the development flow of competencies or expertise.

\section{METHODS}

This research was conducted using this type of research quantitatively, because the data is in the form of numbers and is analyzed by inferential statistical techniques (Manna, 2008). The research was conducted at Vocational High School of RadenPatah, Mojokerto with data collection using a google form questionnaire taken in September 2020. The study population was the students of Vocational High School of RadenPatah, Mojokerto with samples taken by all students of Class XII mechanical engineering competency, totaling 72 students.

This research is included in ex post - facto research where the independent variables have occurred when the researcher started observing the dependent variable (Darmadi, 2013). The instrument used in this study was a questionnaire which contained statements developed from indicators based on relevant theory with each research variable referring to the variables of industrial work experience (Internship), soft skills and student work readiness with four alternative answers, namely Strongly Agree (SA), Agree (S), Neutral (E), Disagree (DS) and Strongly Disagree (SDS). The variables in this study consisted of three variables, namely two independent variables $(\mathrm{X})$, namely industrial work practice experience (X1) and soft skills (X2) and one dependent variable (Y) in the form of work readiness.

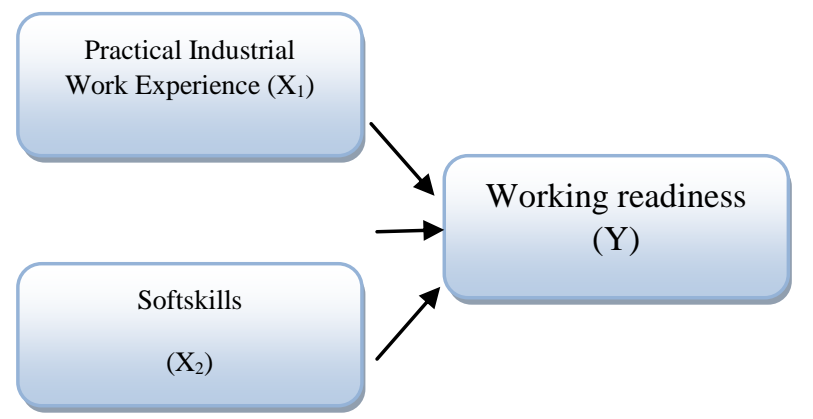

Figure 1. Schematic relationship between variables

The study design used a correlational design, which is looking for a causal correlation with the variables of industrial work practice experience and soft skills on work readiness, as shown in Figure 1 . The data were analyzed using multiple regression tests using SPSS 23 for windows software with a significance level of $5 \%$.

\section{RESULTS AND DISCUSSIONS}

Descriptive analysis of the research results by looking for the number of intervals in order to obtain the variable criteria for industrial work experience (X1), soft skills (X2) and work readiness $(\mathrm{Y})$ which are described as follows.

Table 1. Descriptive Analysis of Industrial Work Experience Variables

\begin{tabular}{ccccc}
\hline No & Interval & $\mathrm{F}$ & Presentase & Criteria \\
\hline 1 & $130-154$ & 19 & $26 \%$ & Very Good \\
2 & $105-129$ & 48 & $67 \%$ & Good \\
3 & $80-104$ & 5 & $7 \%$ & Good enough \\
4 & $55-79$ & 0 & $0 \%$ & Not Good \\
5 & $30-54$ & 0 & $0 \%$ & Not Very Good \\
\hline \multicolumn{2}{c}{ Total } & 72 & $100 \%$ & \\
\hline \multicolumn{2}{l}{ Mean } & & & $121,57 \approx 122$ \\
\hline
\end{tabular}

Based on the table above, it shows that 19 students have work readiness in the Very Good category, 48 students are in the Good category, 5 students are in the Good Enough category and none are included in the Not Good or Very Bad category. Mechanical engineering students have good industrial practical experience. This can be seen in the average industrial practical work experience of 122 and the percentage of $67 \%$ or 48 students. So that class XII students of mechanical engineering at Vocational High School of Raden Patah, Mojokerto has experience in industrial work practices, including the Good category.

Table 2. Descriptive Analysis of Soft Skills Variables

\begin{tabular}{ccccc}
\hline No & Interval & $\mathrm{F}$ & Presentase & Criteria \\
\hline 1 & $130-154$ & 21 & $29 \%$ & Very Good \\
2 & $105-129$ & 46 & $64 \%$ & Good \\
3 & $80-104$ & 5 & $7 \%$ & Good enough \\
4 & $55-79$ & 0 & $0 \%$ & Not Good \\
5 & $30-54$ & 0 & $0 \%$ & Not Very Good \\
\hline
\end{tabular}




\begin{tabular}{|c|c|c|}
\hline Total & 72 & $100 \%$ \\
\hline Mean & & $123,47 \approx 123$ \\
\hline Criteria & & Good \\
\hline
\end{tabular}

Based on the table above, it shows that 21 students have soft skills in the Very Good category, 46 students are in the Good category, 5 students are in the Good Enough category and none are included in the Not Good or Very Bad category. Overall, mechanical engineering students have good soft skills. This can be seen in the average soft skills of 123 and the percentage of $64 \%$ or 46 students. So, that class XII students of mechanical engineering at Vocational High School of Raden Patah, Mojokerto have soft skills including the Good category.

Table 3. Descriptive Analysis of Work Readiness Variables

\begin{tabular}{ccccc}
\hline No & Interval & $\mathrm{F}$ & Presentase & Criteria \\
\hline 1 & $88-104$ & 23 & $32 \%$ & Very Ready \\
2 & $71-87$ & 47 & $65 \%$ & Ready \\
3 & $54-70$ & 2 & $3 \%$ & Simply Ready \\
4 & $37-53$ & 0 & $0 \%$ & Not Ready \\
5 & $20-36$ & 0 & $0 \%$ & Very Unprepared \\
\hline \multicolumn{2}{c}{ Total } & 72 & $100 \%$ & $83,53 \approx 84$ \\
\hline & & & Ready
\end{tabular}

Based on the table above, it shows that 23 students have work readiness in the Very Ready category, 47 students are in the Ready category, 2 students are in the Sufficiently Ready category and none are in the Not Ready or Very Not Ready category. mechanical engineering students have work readiness conditions in the Ready category. This can be seen in the average work readiness of 84 and a percentage of $65 \%$ or 47 students of class XII mechanical engineering at Vocational High School of Raden Patah, Mojokerto stated that they were ready to work.

The Correlation of Industrial Work Experience Experience on Work Readiness

The data collected from the questionnaire was then carried out by testing a simple regression analysis to find out how big the correlation between industrial work practice experience and work readiness is shown in Table 4.

Table 4. Table of Coefficients of Industrial Work Training Experience

\begin{tabular}{ccccccc}
\multicolumn{7}{c}{ Coefficients $^{\mathrm{a}}$} \\
\hline \multirow{2}{*}{ Model } & \multicolumn{1}{c}{$\begin{array}{c}\text { Unstandardized } \\
\text { Coefficients }\end{array}$} & $\begin{array}{c}\text { Standardized } \\
\text { Coefficients }\end{array}$ & $\mathrm{t}$ & Sig. \\
& & B & Std. Error & Beta & & \\
\hline 1 & (Constant) & 44,685 & 8,194 & & 5,454 &, 000 \\
& Prakerin &, 315 &, 066 &, 494 & 4,757 &, 000 \\
\hline
\end{tabular}

a. Dependent Variable: Work Readiness

Table 4 shows that the Sig probability value for the industry practice experience variable (X1) is 0.000 . Because the significance value is $0.000<0.05$ probability, it can be concluded that $\mathrm{HO}$ is rejected and $\mathrm{Ha}$ is accepted, which means that there is a correlation between industrial work experience and work readiness. While the regression coefficient $=0.494$ (marked + or positive) This proves that industrial work practice experience has a positive and significant correlation with work readiness. So, it can be concluded that if the experience of industrial work practice has increased then work readiness will also increase in class XII students of mechanical engineering expertise at Vocational High School of Raden Patah, Mojokerto.

Table 5. Table Model Summary X1*Y Model Summary ${ }^{\mathrm{b}}$

\begin{tabular}{ccccc}
\hline Model & $\mathrm{R}$ & $\mathrm{R}$ Square & $\begin{array}{c}\text { Adjusted R } \\
\text { Square }\end{array}$ & $\begin{array}{c}\text { Std. Error of the } \\
\text { Estimate }\end{array}$ \\
\hline 1 &, $494^{\mathrm{a}}$ &, 244 &, 234 & 5,80732 \\
\hline
\end{tabular}

a. Predictors: (Constant), Internship

Table 5 shows the correlation coefficient (R) of 0.494 and the coefficient of determination (R2) of 0.244 . These results can mean that the magnitude of the correlation of the industrial work experience variable (X1) to the work readiness variable (Y) of the XII grade students of mechanical engineering at Vocational High School of Raden Patah, Mojokerto is $24.4 \%$.

\section{The Correlation of Soft Skills on Work Readiness}

The results of simple regression analysis to determine the correlation of soft skills on work readiness are shown in the table data as follows.

Table 6. Soft Skills Coefficients Table

\begin{tabular}{lcccccc}
\hline \multirow{2}{*}{ Model } & \multicolumn{7}{c}{ Unstandardized } \\
& Coefficients & $\begin{array}{c}\text { Standardized } \\
\text { Coefficients } \\
\end{array}$ & B & Std. Error & Beta & Sig. \\
\hline 1 & (Constant) & 44,409 & 8,043 & & 5,522 &, 000 \\
& Softskills &, 322 &, 066 &, 504 & 4,881 &, 000 \\
\hline
\end{tabular}

a. Dependent Variable: Work Readiness

Table 6 shows that the Sig probability value for the soft skills variable (X2) is 0,000 . If we compare the significance value of $0.000<0.05$ probability, it can be concluded that $\mathrm{HO}$ is rejected and $\mathrm{Ha}$ is accepted, which means that there is a correlation between soft skills and work readiness. While the regression coefficient $=0.504$ (marked + or positive) . This proves that soft skills have a positive and significant correlation to work readiness. So, it can be concluded that if soft skills have increased then work readiness will also increase in class XII students of mechanical engineering expertise at Vocational High School of Raden Patah, Mojokerto.

Table 7. Table Model Summary X2*Y Model Summaryb

\begin{tabular}{ccccc}
\hline Model & $\mathrm{R}$ & R Square & $\begin{array}{c}\text { Adjusted } \mathrm{R} \\
\text { Square }\end{array}$ & $\begin{array}{c}\text { Std. Error of the } \\
\text { Estimate }\end{array}$ \\
\hline 1 &, $504^{\mathrm{a}}$ &, 254 &, 243 & 5,77017 \\
\hline \multicolumn{3}{c}{ a. Predictors: (Constant), Softskills }
\end{tabular}

Table 7 shows the correlation coefficient (R) of 0.504 and the coefficient of determination (R2) of 0.254 . These 
results can mean that the magnitude of the correlation of the soft skills variable (X2) to the work readiness variable (Y) of the XII grade students of mechanical engineering at Vocational High School of Raden Patah, Mojokerto is 25.4\%.

\section{Simultaneous Correlation of Industrial Work \\ Experience and Soft Skills on Work Readiness \\ Correlation of Soft Skills on Work Readiness}

The results of multiple regression analysis testing to determine the simultaneous correlation of industrial work practice and soft skills on work readiness are presented in Table 8.

Table 8. Table of soft skill coefficients and industrial work practices

\begin{tabular}{|c|c|c|c|c|c|c|}
\hline \multicolumn{7}{|c|}{ Coefficients $^{a}$} \\
\hline & & \multicolumn{2}{|c|}{$\begin{array}{l}\text { Unstandardized } \\
\text { Coefficients }\end{array}$} & \multirow{2}{*}{$\begin{array}{c}\text { Standardized } \\
\text { Coefficients } \\
\text { Beta }\end{array}$} & \multirow[b]{2}{*}{$\mathrm{t}$} & \multirow[b]{2}{*}{ Sig. } \\
\hline & Model & B & Std. Error & & & \\
\hline \multirow[t]{3}{*}{1} & (Constant) & 34,932 & 8,743 & & 3,996 & ,000 \\
\hline & Prakerin & 190 & ,080 & 299 & 2,384 & ,020 \\
\hline & Softskills & 206 & ,080 & ,323 & 2,578 & ,012 \\
\hline
\end{tabular}

Based on Table 8, the constant values $(\mathrm{a})=34.932$, b1X1 $=0.299$ and $\mathrm{b} 2 \mathrm{X} 2=0.323$ are obtained. So that the multiple regression line equation can be expressed in the following equation.

$$
\mathrm{Y}=34,932+0,299 \mathrm{X} 1+0,323 \mathrm{X} 2
$$

The regression line equation has a meaning, namely a constant value of 34.932 which states that if there is no increase in the variable of industrial work experience and soft skills, the student's work readiness is 34.932. Then for the first regression coefficient of $0.299 \mathrm{X} 1$ states that each addition (+ sign) 1 industrial work practice experience will increase student work readiness by 0.299 . Conversely, if there is a decrease in the value of 1 (sign -) in the practical industrial work experience, then the students' work readiness is also predicted to decrease by 0.299 . This also applies to other variables, for the regression coefficient of $0.323 \mathrm{X} 2$ states that each addition of 1 to soft skills will increase student work readiness by 0.323 , conversely if there is a decrease of 1 in soft skills, then student work readiness is also predicted to decrease by 0.323 . Thus the conclusion that can be obtained is that the variables of industrial work practice experience (X1) and soft skills (X2) together or simultaneously have a positive and significant correlation to the student work readiness variable (Y).

Table 9. Table Model Summary X1 dan X2*Y

\begin{tabular}{|c|c|c|c|c|}
\hline \multicolumn{5}{|c|}{ Model Summaryb } \\
\hline & & & Adjusted R & Std. Error of the \\
\hline Model & $\mathrm{R}$ & R Square & Square & Estimate \\
\hline 1 &, $557^{\mathrm{a}}$ & ,311 & ,291 & 5,58630 \\
\hline
\end{tabular}

Table 9 shows the value of the correlation coefficient $(\mathrm{R})$, namely $=0.557$ and the coefficient of determination
$(\mathrm{R} 2)=0.311$. This shows that there is a correlation between the variables of industrial work practice experience (X1) and soft skills (X2) simultaneously with work readiness (Y) of $31.1 \%$, while a score of $68.9 \%$ has a correlation with other variables not studied.

Table 10. Test Table F

\begin{tabular}{ccccccc}
\multicolumn{7}{c}{ ANOVA $^{\text {a }}$} \\
\hline \multirow{2}{*}{ Model } & Sum of & & Mean & & \\
\hline 1 & Regression & 970,677 & 2 & 485,338 & 15,552 &, $000^{\text {b }}$ \\
& Residual & 2153,268 & 69 & 31,207 & & \\
& Total & 3123,944 & 71 & & & \\
\hline \multicolumn{6}{c}{ a. Dependent Variable: Work Readiness } \\
\multicolumn{5}{c}{ b. Predictors: (Constant), Softskills, Internship }
\end{tabular}

Table 10 provides information on whether there is a simultaneous correlation between the variables of industrial work practice experience and soft skills on work readiness variables. Based on Table 10 , it is known that the Sig probability value is equal to 0,000 . Because the Sig. $0.000<0.05$, so according to the basis of decision making in the $\mathrm{F}$ test it can be concluded that industrial work practice experience (X1) and soft skills (X2) simultaneously have a correlation with work readiness (Y). The increase in the quality of industrial practical work experience and soft skills is directly proportional and will be followed by an improvement in the level of work readiness of class XII grade students of mechanical engineering at Vocational High School of Raden Patah, Mojokerto.

With the acceptance of the first hypothesis there is a correlation between industrial work practice experience on job readiness of class XII students of mechanical engineering expertise at Vocational High School of Raden Patah, Mojokerto, so it is relevant to Mutoharoh's research (2019) that industrial work practice affects job readiness and a correlation of $13.84 \%$. The results of this study are also in line with previous research conducted by Pratama (2018) which states that there is a significant effect of industrial work practices on student work readiness with a contribution of $16.81 \%$. This is in accordance with research (Vukić, et al, 2020) which suggests that students who have acquired theoretical and practical knowledge through internships can improve work abilities, develop skills through the socialization process in the workplace, and develop work habits and have a better understanding of work culture. Dalyono (2005) suggests that experiences can affect a person's physiology, which is part of the readiness of vocational students to prepare themselves to enter the industrial world. The better the student's industrial practical work experience, the greater the student will increase their work readiness (Muyasaroh, 2013). This shows that practical industrial work experience is a process for students to gain direct experience, both professional knowledge and skills in accordance with their 
field of expertise at IDUKA so that students are equipped and ready to enter the world of work.

With the acceptance of the second hypothesis, there is a correlation between soft skills and work readiness of class XII students of mechanical engineering expertise at Vocational High School of Raden Patah, Mojokerto, according to Yulianti and Khafid's (2015) research that mastery of soft skills affects work readiness and contributes $30.36 \%$. Lisdiantini's (2019) research also states that soft skills have a significant effect on job readiness. The effect is positive, which means that the higher the soft skills you have, the higher the level of work readiness. Success in one's job is not only determined by hard skills but also mastery of soft skills (Afriani, 2015). This is in accordance with the theory put forward by Sucipta (2009) that soft skills have a role in improving diversity management due to a dynamic business environment. The world of industry is very challenging and competitive, so it requires multitasking graduates, so students must learn soft skills related to industrial needs (Jafaar, 2018). So it can be concluded that the mastery of soft skills can improve students' ability to prepare themselves for competition in looking for work.

The acceptance of the third hypothesis is that there is a correlation between industrial work practice experience and soft skills on work readiness of class XII students of mechanical engineering expertise at Vocational High School of Raden Patah, Mojokerto. If the student's industrial work practice experience and soft skills are good, the student has good readiness to enter the world of work, and vice versa, if the experience of industrial work practice and soft skills mastery is lacking, it can be said that the student has less readiness to enter the world of work. Industrial practical work experience and soft skills are part of the factors that affect job readiness. Students who have experienced industrial practical work and soft skills have not only improved their mastery of soft skills but have also improved their hard skills through hands-on experience in the world of work by following industrial work practices. This is in line with Kardimin's (2004) opinion that there are two factors that affect job readiness, namely internal factors and extrenal factors. Where internal factors include physical and mental maturity, mint, talent, intelligence, motivation andmastery of science. Meanwhile, external factors include the role of the community, family, information on job vacancies and work experience.

This research shows that in the implementation of the student learning process it is expected that there will be coverage such as communication, skills for both alone and in groups or in society, cooperation, responsibility, honesty and adaptation, so that aspects of soft skills can be fulfilled. The indicators contained in the soft skills are the main characters as human beings who are able to communicate well, are willing to cooperate with people around them, are responsible, honest and able to adapt to the people around them. This is the key to success, when entering the world of work. Can make a workforce that is responsive, caring, polite and above all honest. A number of competencies will be important in line with the demands of the workforce Mastery of a number of work competencies provided by the school and practical industrial work experience will be important for work readiness of students who are graduates of Vocational High School of Raden Patah, Mojokerto. Because with adequate work readiness, graduates can complete their assigned work without experiencing significant difficulties or obstacles and getting maximum results.

\section{CONCLUSION}

Based on the data analysis and the discussion above, it can be concluded as follows: (1) there is a significant correlation with the direction of a positive relationship between industrial work practice experience and work readiness in class XII students of mechanical engineering at Vocational High School of RadenPatah, Mojokerto of $24.4 \%$ (2) there is a significant correlation with the direction of the positive relationship between soft skills and work readiness in XII grade students of the mechanical engineering at Vocational High School of RadenPatah, Mojokerto of $25.4 \%$ (3) there is a significant correlation with the direction of a positive relationship between industrial work practice experience and soft skills simultaneously on work readiness in class XII students of mechanical engineering at Vocational High School of RadenPatah, Mojokerto of 31.1\%.

\section{Acknowledgement}

The authors would like to thank all those who have helped in completing this research.

\section{Conflict of Interest}

The authors declare that they have no competing interests.

\section{REFERENCES}

Abdullah-Al-Mamun, M. (2012). The soft skills education for the vocational graduate: Value as work readiness skills. Journal of Education, Society and Behavioural Science, 326338.

Afriani, R., \& Setiyani, R. (2015). Pengaruh Persepsi Siswa tentang Kompetensi Kejuruan, Penguasaan Soft Skill, dan Kematangan Karir terhadap Kesiapan Kerja Siswa Kelas XII Akuntansi SMK Negeri 2 Magelang TahunAjaran 2014/2015. Economic Education Analysis Journal, 4(2).

Badan Pusat Statistik. (2020). Februari 2019: Tingkat Pengangguran Terbuka (TPT) sebesar 5,01 persen. Diaksesdari

https://www.bps.go.id/pressrelease/2020/05/05/1672/februari -2020--tingkat-pengangguran-terbuka--tpt--sebesar-4-99persen.html pada tanggal 30 September 2020. 
Caballero, C. L., Walker, A., \& Fuller-Tyszkiewicz, M. (2011). The Work Readiness Scale (WRS): Developing a measure to assess work readiness in college graduates. Journal of teaching and learning for graduate employability, 2(2), 4154.

Chaplin, C. P. (2006). Kamus lengkap psikologi. Jakarta: Raja Grafindo Persada.

Dalyono.(2005). Psikologi Pendidikan. Jakarta: Rineka Cipta.

Darmadi, Hamid. (2013). Metode Penelitian Pendidikan dan Sosial. Bandung: Alfabeta.

Dikmenjur. (2013). Pedoman Pelaksanaan Prakerin. Jakarta: Direktorat Pembinaan Sekolah Menengah Kejuruan, Depdiknas.

Firdaus Z. Z, (2012). Pengaruh Unit Produksi, Prakerin dan Dukungan Keluarga Terhadap Kesiapan Kerja Siswa SMK. Jurnal Pendidikan Vokasi, 3 (2).

Fitriyanto A. (2004). Ketidakpastian Memasuki Dunia Kerja karena Pendidikan. Jakarta: RinekaCipta.

Goleman,.(2016). Emotional Intelligence (Kecerdasan Emosional). Jakarta:Gramedia Pustaka Utama.

Hamalik 0. (2007). Pengembangan SDM Pelatihan Ketenagakerjaan Pendidikan Terpadu. Jakarta: PT Bumi Aksara.

Illah Sailah. Pengembangan Soft skills di Perguruan Tinggi. Jakarta: Direktorat Jenderal.

Instruksi Presiden No 9 Tahun 2016 tentang revitalisasi SMK.

Iskandar, T.A.Z.H, Nurhadjo, B, Krishnabudi, N.G. (2014). "Pengaruh hard skills dan soft skills terhadap kecenderungan keingainan pemilihan bidang kerja melalui kepercayaan dari mahasiswa (Studi pada mahasiswa jurusan manajemen Fakultas Ekonomi Universitas Jember." Artikel ilmiah maha siswa: 1-7.

Jaafar, S. B. (2018). Are Soft Skills Required for Accounting Students in Future Careers?.Available at SSRN 3167595.

Kardimin, A. (2004). Strategi Melamar Kerja dan Bimbingan Karier. Jakarta: Bumi Aksara.

Malhi RS. (2020). The Hard Truth about Graduate Employability and Soft Skills. 2010; Accessed 31 October, 2020. Available:http://www.daffodilvarsity.edu.bd/ctlbd/images/the hard_truth_about_graduate_employability_and_soft_skills-1.pdf.
Muqowim, Pengembangan Soft Skill Guru. (Yogyakarta: Pedagogia, (2012), Pendidikan Tinggi, 2008).

Muyasaroh, H. B. 2013. pengaruhpengalamanpraktikkerjaindustri dan locus uf control terhadapkesiapankerjasiswakelas XII SMK Negeri 1 Surakarta. Jurnal Pendidikan Ekonomi UNS, 1(1): 1- 11.

Peraturan pemerintah Nomor 29 tahun 1990 tentang pendidikan menengah.

Peraturan Menteri Pendidikan dan Kebudayaan Republik Indoensia Nomor 22 Tahun 2020 Tentang Rencana Strategis Kementerian Pendikan Dan Kebudayaan tahun 2020.

Pratama Y dkk. (2018). Hubungan Praktek Kerja Industri Dengan Kesiapan Kerja Siswa SMK Negeri 1 Cibinong Kelas XII Kompetensi Keahlian Teknik Gambar Bangunan, Jurnal Pendidikan Teknik Sipil, 7(1).

Putra, Ikhsan S., dan Aryanti Pratiwi. Sukses dengan Soft Skills. (Bandung: ITB. 2005).

Rani, E.M.S. (2010)."Need and Importance of Soft Skills in Student”. Vol,-II 3 Januari-Juni (Summer) 2010. Associate Professor in English, Sri Sarada College for Women, Salem636016.

Sucipta, I Nyoman. (2009). Holistik soft skills. Bali: Udayana University press.

Sugihartono, dkk. (2007). Psikologi Pendidikan. Yogyakarta: UNY Pers.

Teng, W., Ma, C., Pahlevansharif, S., \& Turner, J. J. (2019). Graduate readiness for the employment market of the 4 th industrial revolution. Education Training.

Vukić, M., Kuzmanović, M., \&Vukić, M. (2020). Students' perspective of internship in vocational higher education. Management: Journal of Sustainable Business and Management Solutions in Emerging Economies.

Wagiran, W. (2008). The Importance of Developing Soft Skills in Preparing Vocational High School Graduates. SEAVERN Journals, 1(1).

Yulianti, I., \&Khafid, M. (2015). Pengaruh Pengalaman Praktik Kerja Industri, Motivasi Memasuki Dunia Kerja, dan Kemampuan Soft Skills Terhadap Tingkat Kesiapan Kerja Siswa Kelas XII Kompetensi Keahlian Akuntansi di SMK Negeri 2 Semarang Tahun Ajaran 2014/2015. Economic Education Analysis Journal, 4(2). 